\title{
Implications of land rights reform for Indigenous health
}

\author{
Nicole L Watson
}

O ver the past year, there has been a great deal of speculation about the benefits of Indigenous land rights. Advocates for reform commonly argue that poor living standards in remote communities are evidence of the failure of the "land rights revolution". Their campaign crystallised in August when the Aboriginal Land Rights (Northern Territory) Amendment Bill 2006 (Cwlth) passed into law, introducing a scheme for 99-year leases over Indigenous lands.

I argue that the leasing scheme is potentially detrimental to Indigenous health, as it will deprive traditional owners of control over their lands. Here, I discuss the links between ownership and control over traditional lands and health. I then discuss the history of the Aboriginal Land Rights (Northern Territory) Act 1976 (Cwlth) and analyse the recent reforms.

\section{The nexus between land and health}

Like any other group in society, Indigenous people have a diversity of opinion, and therefore there is no such thing as an essential Indigenous perspective. However, it is undisputed that land is at the core of Indigenous beliefs, law and identity. The anthropologist Deborah Bird Rose described Indigenous land relationships in the following terms:

The relationships between people and their country are intense, intimate, full of responsibilities, and, when all is well, friendly. It is a kinship relationship, and like relations among kin, there are obligations of nurturance. People and country take care of each other. ${ }^{2}$

So, it is unsurprising that land rights have been the most enduring demand of the Indigenous political movement. Although the issue did not enter the public consciousness until the Gurindji strike in 1966, ${ }^{3}$ Indigenous people had been petitioning colonial governments for land since the 19th century. ${ }^{4}$ Over time, their claims have been variously couched in the language of civil and political rights and health. As stated by Pat Anderson, former Chair of the National Aboriginal Community Controlled Health Organisation:

Our identity as human beings remains tied to our land, to our cultural practices, our systems of authority and social control, our intellectual traditions, our concepts of spirituality, and to our systems of resource ownership and exchange. Destroy this relationship and you damage - sometimes irrevocably individual human beings and their health. ${ }^{5}$

Arguments based on health have gained little traction at the political level, in spite of the steady growth of research suggesting a link between land rights and improved health. For example, in the mid 1970s, Morice compared conditions of a fledgling outstation, Kungkayunti, with those of the government settlement of Papunya. ${ }^{6}$ Morice observed that residents of Kungkayunti obtained at least half of their food supplies from hunting and foraging, whereas those at Papunya obtained virtually all their food from the government store. While the outstation was relatively autonomous, Papunya was effectively governed by non-Indigenous public servants. Of the two groups, the residents of Kungkayunti had not only superior physical health, but also greater self-

\section{ABSTRACT}

- In August 2006, the Aboriginal Land Rights (Northern

Territory) Amendment Bill 2006 (Cwlth) was passed into law, introducing, among other things, a system of 99-year leases over Indigenous townships.

- The leasing scheme will diminish the control that traditional owners previously exercised over their lands.

- This is at odds with research indicating that control over land is a positive influence on Indigenous health.

MJA 2007; 186: 534-536

esteem. Two decades later, McDermott and others compared the health of Aboriginal adults living on the homelands with those in centralised communities. ${ }^{7}$ The former had lower rates of diabetes, cardiovascular risk factors, hospitalisation and death.

Proponents for land rights reform have correctly pointed out that, despite three decades of land rights, the health of Indigenous Australians has not improved as dramatically as that of the Indigenous populations of New Zealand and North America. However, there is an important historical distinction - unlike New Zealand or North America, Australia never had a treaty recognising the sovereignty of Indigenous groups.

The consistent denial of Indigenous sovereignty may be a factor explaining such discrepancies. ${ }^{8}$ This argument is analogous to Syme's hypothesis that control of one's destiny, or "mastery", is an important determinant of health. ${ }^{9}$ It is also consistent with research from Canada suggesting that Indigenous communities that have reclaimed a degree of self-government have better health than those that have not done so. An examination of youth suicide rates of 196 First Nations groups in British Columbia found that, while some groups suffered rates 800 times the national average, suicide was non-existent in just over half. ${ }^{10}$ The authors hypothesised that the latter group had given its members a sense of cultural continuity that protected individuals from suicidal behaviour. The hypothesis was tested by analysing six variables that included taking steps to secure title to traditional lands, reclaiming rights of self-government, control over health services, and the existence of facilities to maintain culture. In communities with all six variables, the youth suicide rate was zero for the 5 -year study period. ${ }^{10}$

What is the message for Australian policymakers? Although the links are yet to be defined with precision, it appears that Indigenous groups who not only regain ownership of their traditional lands, but also exercise genuine control over their affairs, enjoy improved health. Consequently, if existing land rights legislation is to be amended, it should be for the purpose of expanding its application and enhancing the decision-making powers of traditional owners. However, the recent amendments to the Aboriginal Land Rights (Northern Territory) Act were a step in the opposite direction.

\section{The Aboriginal Land Rights Act 1976}

As distinct from other common law jurisdictions, Australia was settled on the basis of terra nullius, with the result that traditional 
land titles were denied legal recognition. The invisibility of traditional land titles was confirmed by the Northern Territory Supreme Court in the 1971 case of Milirrpum v Nabalco Pty Ltd, ${ }^{11}$ effectively confining the issue to the political arena. Largely in response to Indigenous activism, state land rights regimes emerged, beginning with the Aboriginal Lands Trust Act 1966 (SA). However, at the Commonwealth level, there was no real change until the election of the Whitlam Labor Government in 1972. The following year, Justice Edward Woodward was appointed to the first commission of inquiry into Aboriginal land rights. The Aboriginal Land Rights (Northern Territory) Act of 1976 ("ALRA") was the result of Woodward's reports. ${ }^{12,13}$

The ALRA made provision for the transfer of Aboriginal reserves to Land Trusts that hold the titles on behalf of traditional owners. The Act also established a process for land claims to be determined by an Aboriginal Land Commissioner. Over the past three decades, Aboriginal people have managed to regain some $44 \%$ of all land in the Northern Territory. ${ }^{14}$

The title is equivalent to freehold, but is inalienable and held communally, in accordance with Indigenous cultural values. It has always been possible for Land Trusts to grant interests over Indigenous lands. However, a Land Trust could only do so at the direction of the relevant Land Council, which was obliged to ensure that the traditional owners understood the nature and purpose of the grant, and that the terms of the grant were reasonable. ${ }^{15}$ Arguably, these safeguards are entirely consistent with cultural values that cast obligations on the living to preserve the land for future generations.

The Aboriginal Land Rights (Northern Territory) Amendment Bill of 2006 represented the most far-reaching change to the ALRA since its enactment; it touches on the Act's mining provisions, the powers, functions and funding of Aboriginal Land Councils, and the leasing of Aboriginal land. But even before this Act became law, any control that Indigenous people may have had over the changes was denied. There was no consultation program and, even though the Bill was the subject of an inquiry by the Senate Community Affairs Legislation Committee, the time frame was so tight that the Committee's only public hearing lasted for 1 day. ${ }^{16}$ The resulting powerlessness on the part of traditional owners was captured by the submission of the Laynhapuy Homelands Association:

The changes the Government are making to Indigenous affairs generally, and in this case Land Rights, are happening much too quickly for our people to understand, let alone respond to. This is placing enormous stress on our leaders, and the sense of "loss of control" and powerlessness to respond is resulting in demoralisation, depression and fatigue. ${ }^{17}$

Such powerlessness will be exacerbated by a scheme for the leasing of Indigenous townships. The ostensible purpose of the scheme is to promote private investment. Traditional owners will have the choice of granting 99-year leases over townships to a new government entity that will be responsible for negotiating subleases. The government entity will be under no obligation to obtain the concurrence of traditional owners when granting subleases. ${ }^{18}$ Theoretically, undesirable businesses such as pubs and fast-food outlets could be established over the wishes of traditional owners. The loss of control would be perpetuated by the lengthy duration of the leases, which will effectively span three generations.

Another objective of the leasing scheme is to encourage home ownership by Indigenous residents of townships. However, residents may not necessarily be traditional owners of the land.
Consequently, it is possible that, just as traditional owners lose control over their land, historical owners will have their rights increased, inevitably leading to future conflict.

Although the Commonwealth has been at pains to point out that entry into the scheme is voluntary, this is open to doubt. In November, the Thamarrurr Council of Wadeye alleged that the Commonwealth was withholding $\$ 10$ million for desperately needed housing until the community agreed to grant a 99-year lease. ${ }^{19}$ Likewise, the Commonwealth has pledged to fund a boarding school for Tiwi Island youth on the condition that the community also grant a 99 -year lease. ${ }^{20}$ Both cases raise the issue of free and informed consent. Wadeye is one of the poorest communities in the country, and only $10 \%$ of Tiwi Island youth have attained basic literacy skills. ${ }^{20}$ If the only means for parents to house and educate their children is a 99-year lease, it is difficult to argue that their consent is freely given.

The possibility that access to medical treatment will also be used as a bargaining chip should not be dismissed, as there are precedents for such agreements. For example, in 1998 the Jawoyn people withdrew a native claim in exchange for an alcohol rehabilitation centre and two renal dialysis machines. ${ }^{21}$ Eight years ago, such agreements were rare, but with the proliferation of shared responsibility agreements, ${ }^{22}$ it is possible that in the future Indigenous groups will be forced to choose between access to medical treatment and control over their traditional lands.

\section{Conclusion}

Over the past 30 years, there has been a steady growth in research indicating that Indigenous people who regain ownership and control of their traditional lands enjoy improved health. The recent amendments to the ALRA, particularly the township leasing scheme, are steps in the opposite direction, as they will usurp the authority of traditional owner groups. Although the health impacts are impossible to predict, early reports of powerlessness created by the lack of consultation and the use of infrastructure as an enticement into the scheme are cause for concern.

\section{Competing interests}

None identified.

\section{Author details}

Nicole L Watson, LLB, LLM, Senior Research Fellow Jumbunna Indigenous House of Learning, University of Technology Sydney, Sydney, NSW.

Correspondence: nicole.watson@uts.edu.au

\section{References}

1 Johns G. Leaving home lands. The Australian 2006; 7 Feb.

2 Rose DB. Nourishing terrains: Australian Aboriginal views of landscape and wilderness. Canberra: Australian Heritage Commission, 1996: 49.

3 Deane W. Some signposts from Daguragu. The Inaugural Lingiari Lecture delivered by Sir William Deane, Governor General of the Commonwealth of Australia, at the invitation of the Council for Aboriginal Reconciliation, Darwin, Thursday 22 August 1996. Australasian Legal Information Institute. http://www.austlii.edu.au/au/other/IndigLRes/1996/2/index.html (accessed Dec 2006).

4 Goodall H. Invasion to embassy. Sydney: Allen and Unwin, 1996

5 Anderson P. Priorities in Aboriginal health. In: Robinson G, editor. Aboriginal health: social and cultural transitions. Darwin: Northern Territory University Press, 1996. 


\section{HEALTH SERVICES}

6 Morice RD. Woman dancing dreaming. Psychosocial benefits of the Aboriginal outstation movement. Med J Aust 1976; 2: 939-942.

7 McDermott R, O'Dea K, Rowley K, et al. Beneficial impact of the homelands movement on health outcomes in Central Australian Aborigines. Aust N Z J Public Health 1998; 22: 653-658.

8 Ring IT, Firman D. Reducing Indigenous mortality in Australia: lessons from other countries. Med J Aust 1998; 169: 528-533.

9 Swan N. Mastering the control factor, part one. Interview with L Syme [transcript of radio broadcast]. The Health Report, Radio National, Nov 9 1998. http://www.abc.net.au/rn/talks/8.30/helthrpt/stories/s14314.htm (accessed Mar 2006).

10 Chandler MJ, Lalonde C. Cultural continuity as a hedge against suicide in Canada's first nations. Transcult Psychiatry 1998; 35: 191-219.

11 Milirrpum v Nabalco Pty Ltd (1971) 17 FLR 141.

12 Woodward AE. Aboriginal Land Rights Commission: first report. Canberra: AGPS, 1973.

13 Woodward AE. Aboriginal Land Rights Commission: second report. Canberra: AGPS, 1974.

14 Norberry J, Gardiner-Garden J. Laws and Bills Digest Section \& Social Policy Section. Aboriginal Land Rights (Northern Territory) Amendment Bill 2006. Parliamentary Library information analysis and advice for the Parliament. Canberra. Bills Digest 2006;158: 3.

15 Aboriginal Land Rights (Northern Territory) Act 1976 (Cwlth) s. 19.
16 Senate Community Affairs Legislation Committee. Provisions of Aboriginal Land Rights (Northern Territory) Amendment Bill 2006. 1 Aug 2006. Canberra: Parliament of the Commonwealth of Australia, 2006. http:// www.aph.gov.au/Senate/committee/clac_ctte/aborig_land_rights/ report/index.htm (accessed Dec 2006).

17 Laynhapuy Homelands Association Inc. Submission to the Senate Community Affairs Committee, Inquiry into the Aboriginal Land Rights (Northern Territory) Amendment Bill 2006. http://www.aph.gov.au/SENATE/ COMMITTEE/clac_ctte/aborig_land_rights/submissions/sub06.pdf (accessed Dec 2006).

18 Aboriginal Land Rights Act 1976 (Cwlth) s. 19A(14).

19 ABC News Online. Brough "bullying" Wadeye into signing 99-year lease. 17 Nov 2006. http://www.abc.net.au/news/newsitems/200611/ s1791655.htm (accessed Dec 2006).

20 Island "held to ransom" over land. The Weekend Australian 2006; 9 Nov. http://www. theaustralian.news.com.au/printpage/0,5942,20 729494,00.html (accessed Dec 2006).

21 Loff B, Cordner S. Aboriginal people trade land claim for dialysis. Lancet 1998; 352: 1451

22 Collard KS, D'Antoine HA, Eggington DG, et al. "Mutual" obligation in Indigenous health: can shared responsibility agreements be truly mutual? Med J Aust 2005; 182: 502-504.

(Received 3 May 2006, accepted 12 Dec 2006) 